\title{
Comparison between the effect of Two Regimens for Hepatitis C Treatment (Qurevo and Ribavirin) and (Sofosbuvir, Daclatsvir and Ribavirin) on Patients above and below the Age of 60 Years \\ Mahmoud Abd El Majeed Othman, Motaz Mohamed Saied Abd EL Mawjood, Mohamed Osama Aly \\ Aly, Aya Ahmed Morsy El Ghamry \\ Department of Internal Medicine, Faculty of Medicine, AinShams University \\ Corresponding author: Aya Ahmed Morsy El Ghamry, E-mail: drayaahmed@ yahoo.com, Mobile: 01008602806.
}

\begin{abstract}
Background: the goal of antiviral treatment is to prevent complications of the disease, mainly cirrhosis and HCC. New therapy options, known as direct acting antiviral (DAA) regimens, offer the promise of increased success rates complimented by shorter treatment durations, improve side effect profiles, and simplified treatment monitoring.

Aim of the Work: to compare between the effect of oral antiviral treatment especially (Quervo and Ribavirin) and (Sofosbuvir, Daclatasvir and Ribavirin) between elderly patients above 60 years and young people below this age as regard: Response to treatment, Development of complication.

Patients and Methods: the study was conducted on 100 Egyptian patients they were divided into 2 groups each one received one of the two treatment regimens then each group divided into 2 subgroups, subgroup A include patients below 60 years and subgroup B include patients above 60 years. The selected patients were subjected to History taking, Complete physical examination, Pelviabdominal ultrasound, Laboratory investigations: complete blood count, bilirubin and liver enzymes before and after treatment, INR, creatinine, albumin, HBs Ag, HIV antibodies and Alpha feto proteins, HCV RNA.

Results: there is no significant difference between two treatment regimens. Both regimens show cure rate about 94\%, 96\% achieved SVR with (sofosbuvir daclatasvir and ribavirin regimen), (quervo and ribavirin regimen) respectively. Both regimens are effective in elderly patients above 60 years as young patients below this age in both regimens, response of treatment in both regimens in elderly patients above 60 years is $96 \%$. Gender doesn't affect treatment outcome. Anemia develop in $34 \%$ of patients receiving sofosbuvir, daclatasvir and ribavirin regimen, and in 58\% of patients receiving quervo and ribavirin regimen. Females developed anemia more frequent than males in both regimens. Both regimens developed hepatobiliary complication, 12\%, 18\% developed hyperbilirubinemia with (sofosbuvir daclatasvir and ribavirin regimen), (quervo and ribavirin regimen) respectively.

Conclusion: treatment with (sofosbuvir daclatasvir and ribavirin regimen) or (quervo and ribavirin regimen) is highly effective with little differences between them; also age and gender have no role in achieving SVR. Complications such as anemia and hyperbilirubinemia occur in treatment with both regimens and more frequent with (quervo and ribavirin regimen).
\end{abstract}

Keywords: Sofosbuvir, Daclatasvir, Quervo, Ribavirin, SVR

\section{INTRODUCTION}

Left untreated, chronic HCV infection can cause liver cirrhosis, liver failure and HCC. Of those with chronic HCV infection, the risk of cirrhosis of the liver is $15-30 \%$ within 20 years ${ }^{(\mathbf{1})}$. The risk of HCC in persons with cirrhosis is approximately $2-4 \%$ per year ${ }^{(2)}$. Elderly patients with chronic $\mathrm{HCV}$ infection have been an understudied population due to several factors. These factors include exclusion of subject older than 65 years of age in several clinical trials, reluctance to treat $\mathrm{HCV}$ infection in elderly due to fear of dealing with more $\mathrm{HCV}$ therapy related adverse effects, co morbidities and risk factors of aging such as decreased glomerular filteration rate that may cause more severe hemolytic anemia with ribavirin and interactions of interferon and ribavirin with several potential geriatric drugs ${ }^{(3)}$. Paritaprevir, a protease inhibitor boosted with ritonavir, and ombitasvir, an NS5A inhibitor, are effective for the treatment of persons infected with genotype $4 \mathrm{HCV}$ (4). Sofosbuvir has shown a good safety profile in clinical trials; an overall improved tolerability was seen with sofosbuvir compared to interferon based regimens ${ }^{(5)}$.

\section{AIM OF THE WORK}

To compare between the effect of oral antiviral treatment especially (Quervo and Ribavirin) and (Sofosbuvir, Daclatasvir and Ribavirin) between elderly patients above 60 years and young people below this age as regard: Response to treatment, Development of complication.

\section{PATIENTS AND METHODS}

This is a case control study that was conducted on 100 Egyptian patients, 50 patients received (Sofosbuvir, Daclatasvir and Ribavirin) and other 50 patients received (Quervo and 
Ribavirin). Patients were recruited in the virology unit, Ahmed Maher Teaching Hospital and Ain Shams University. With following Inclusion criteria: Hepatitis C Ab positive patients, Patients 18 years or older, HCV RNA >15 at initial screening, and exclusion criteria: Patients with decompensated liver cirrhosis (Child Pugh B or C), Patients with hepatocellular carcinoma, Coinfected patient with HBV or HIV. Patients were assigned into: Group (A): include 50 patients below 60 years subdivided into two subgroups each subgroup received one of the two treatment regimens. Group (B): include 50 patients above 60 years subdivided into two subgroups each subgroup received one of the two treatment regimens. Patients approval was taken through informed consent then all patients were subjected to: History taking, Complete physical examination search for signs of decompensation, Pelviabdominal ultrasound: identified focal lesions cirrhosis, splenomegaly and pelvic collections, Laboratory investigatons: complete blood count, bilirubin and liver enzymes before and after treatment, INR, creatinine, albumin, HBs Ag, HIV antibodies and Alpha feto proteins, HCV RNA in serum or plasma by a sensitive qualitative and quantitative molecular method. Ethical considerations: The study was approved by the Ethics Board of Ain Shams University and an informed written consent was taken from each participant in the study.

Statistical analysis: Collected information were coded, tabulated, and analyzed using IBM spss statistics (Statistical Package for Social Sciences) software version 22.0, IBM corp., Chicago, USA, 2013. Statistically descriptive information were done for quantitative information as minimum \& maximum of range and mean \pm SD (standard deviation). Inferential analysis was done for quantitative variables using independent T-test in cases of two independent groups with normally distributed data. Inferential analyses in qualitative information, for independent variables were done using Chi square test for differences between proportions. The level of significance was estimated by $p$-value $<0.050$ is significant, otherwise is non-significant.

\section{RESULTS}

Table (1): Compares response of treatment between two regimens: shows that both regimens are effective with $\mathrm{p}$ value $<0.05$ with no different in treatment with either regimen

\begin{tabular}{|c|c|c|c|c|c|}
\hline \multirow{2}{*}{\multicolumn{2}{|c|}{ PCR }} & \multicolumn{2}{|c|}{ Groups } & \multicolumn{2}{|c|}{ T-Test } \\
\hline & & \begin{tabular}{c|} 
Sofosubuvir \\
Daclatasvir \\
and Ribavirin
\end{tabular} & $\begin{array}{l}\text { Quervo and } \\
\text { Ribavirin }\end{array}$ & t & P-value \\
\hline Before & $\begin{array}{l}\text { Mean } \\
\pm \text { SD }\end{array}$ & $\begin{array}{c}2701059.340 \pm \\
5361347.688\end{array}$ & $\begin{array}{l}3666460.880 \pm \\
9762455.022\end{array}$ & -0.613 & 0.541 \\
\hline After & $\begin{array}{l}\text { Mean } \\
\pm \text { SD }\end{array}$ & $\begin{array}{l}28559.240 \pm \\
129799.959 \\
\end{array}$ & $\begin{array}{l}190419.920 \pm \\
1282093.125\end{array}$ & -0.888 & 0.373 \\
\hline Differences & $\begin{array}{l}\text { Mean } \\
\pm \text { SD }\end{array}$ & $\begin{array}{c}2672500.100 \pm \\
5370315.807\end{array}$ & $\begin{array}{l}3476040.960 \pm \\
9904851.781 \\
\end{array}$ & & \\
\hline Paired Test & 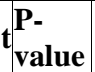 & $0.001^{*}$ & $0.017^{*}$ & & \\
\hline
\end{tabular}

Table (2): Compares response of treatment with sofosbuvir, daclatasvir and ribavirin regimen between patients below and above 60 years: shows no differences as regarding age

\begin{tabular}{|c|c|c|c|c|c|}
\hline \multirow{2}{*}{\multicolumn{2}{|c|}{$\begin{array}{c}\text { PCR Sofosubuvir } \\
\text { Daclatasvir and } \\
\text { Ribavirin }\end{array}$}} & \multicolumn{2}{|c|}{ Subgroups } & \multicolumn{2}{|c|}{ T-Test } \\
\hline & & \multirow{2}{*}{\begin{tabular}{|c|} 
Group A \\
$2078234.840 \pm$ \\
2090515.163 \\
\end{tabular}} & \multirow{2}{*}{ 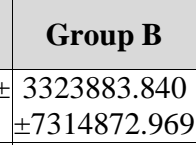 } & \multirow{2}{*}{$\begin{array}{c}\mathbf{t} \\
- \\
0.819 \\
\end{array}$} & \multirow{2}{*}{\begin{tabular}{|c|}
$\begin{array}{c}\text { P- } \\
\text { value }\end{array}$ \\
0.417
\end{tabular}} \\
\hline Before & $\begin{array}{l}\text { Mean } \\
\pm \text { SD }\end{array}$ & & & & \\
\hline After & $\begin{array}{l}\text { Mean } \\
\pm \text { SD }\end{array}$ & $\begin{array}{l}50136.560 \pm \\
179484.402 \\
\end{array}$ & $\begin{array}{c}6981.920 \\
\pm 34834.600 \\
\end{array}$ & 1.180 & 0.244 \\
\hline Differences & $\begin{array}{l}\text { Mean } \\
\pm \text { SD }\end{array}$ & $\begin{array}{c}2028098.280 \pm \\
2119487.832\end{array}$ & $=\begin{array}{l}3316901.920 \\
\pm 7316072.853\end{array}$ & & \\
\hline $\begin{array}{l}\text { Paired } \\
\text { Test }\end{array}$ & P-value & $<0.001 *$ & $0.033^{*}$ & & \\
\hline
\end{tabular}

Table (3): Compares response of treatment with quervo and ribavirin regimen between patients below and above 60 years: shows no differences as regarding age

\begin{tabular}{|c|c|c|c|c|c|}
\hline \multirow{2}{*}{\multicolumn{2}{|c|}{$\begin{array}{l}\text { PCR Quervo } \\
\text { and Ribavirin }\end{array}$}} & \multicolumn{2}{|c|}{ Subgroups } & \multicolumn{2}{|c|}{ T-Test } \\
\hline & & Group A & Group B & $\mathbf{T}$ & P-value \\
\hline Before & $\begin{array}{c}\text { Mean } \\
\pm \text { SD }\end{array}$ & $\begin{array}{c}2651942.360 \pm \\
2837224.103\end{array}$ & $\begin{array}{l}4680979.400 \pm \\
13578954.778\end{array}$ & $\begin{array}{c}- \\
0.731\end{array}$ & 0.468 \\
\hline After & $\begin{array}{c}\text { Mean } \\
\pm \text { SD }\end{array}$ & \begin{tabular}{|l|}
$362558.320 \pm$ \\
1812716.600
\end{tabular} & $\begin{array}{c}18281.520 \pm \\
91332.600\end{array}$ & 0.948 & 0.348 \\
\hline Differences & $\begin{array}{c}\text { Mean } \\
\pm \text { SD }\end{array}$ & \begin{tabular}{|c|}
$2289384.040 \pm$ \\
3616694.385 \\
\end{tabular} & $\begin{array}{l}4662697.880 \pm \\
13575190.515\end{array}$ & & \\
\hline $\begin{array}{c}\text { Paired } \\
\text { Test }\end{array}$ & P-value & $0.004 *$ & 0.099 & & \\
\hline
\end{tabular}


Table (4): Compares the effect of gender on outcome of HCV treatment with both regimens: shows that gender has no role on effectiveness of HCV treatment

\begin{tabular}{|c|c|c|c|c|c|}
\hline \multirow{3}{*}{ Groups } & \multirow{3}{*}{ PCR } & \multicolumn{2}{|c|}{ Gender } & \multirow{2}{*}{\multicolumn{2}{|c|}{ T-Test }} \\
\hline & & \multirow{2}{*}{$\begin{array}{c}\text { Male } \\
\text { Mean } \pm \text { SD }\end{array}$} & \multirow{2}{*}{$\begin{array}{c}\text { Female } \\
\text { Mean } \pm \text { SD }\end{array}$} & & \\
\hline & & & & $\mathbf{T}$ & P-value \\
\hline \multirow{2}{*}{$\begin{array}{l}\text { Sofosubuvir } \\
\text { Daclatasvir } \\
\text { and Ribavirin }\end{array}$} & Before & $\begin{array}{c}2478374.682 \pm \\
3274101.546\end{array}$ & $=2876025.857 \pm$ & -0.258 & \begin{tabular}{|l|l} 
& 0.798
\end{tabular} \\
\hline & After & $\begin{array}{l}29158.545 \pm \\
104591.178\end{array}$ & $\begin{array}{l}28088.357 \pm \\
148550.243\end{array}$ & 0.029 & 0.977 \\
\hline \multirow{2}{*}{$\begin{array}{c}\text { Quervo and } \\
\text { Ribavirin }\end{array}$} & Before & e $\begin{array}{l}5374092.905 \pm \\
14865421.269\end{array}$ & $\begin{array}{l}2429899.759 \pm \\
2273891.535\end{array}$ & 1.054 & 0.297 \\
\hline & After & $\begin{array}{l}431614.190 \pm \\
1977835.960\end{array}$ & $\begin{array}{c}15762.000 \pm \\
84800.190\end{array}$ & 1.135 & 0.262 \\
\hline
\end{tabular}

Table (5): Compares the development of anemia with both regimens: shows significant increase of anemia with both regimens and increased incidence with quervo and ribavirin regimen

\begin{tabular}{|l|l|c|c|c|c|}
\hline \multirow{2}{*}{\multicolumn{2}{|c|}{ Hb }} & \multicolumn{2}{c|}{ Groups } & \multicolumn{2}{c|}{ T-Test } \\
\cline { 3 - 6 } & $\begin{array}{c}\text { Sofosubuvir } \\
\text { Daclatasvir and } \\
\text { Ribavirin }\end{array}$ & $\begin{array}{c}\text { Quervo and } \\
\text { Ribavirin }\end{array}$ & T & P-value \\
\hline Before & $\begin{array}{l}\text { Mean } \\
\pm \text { SD }\end{array}$ & $13.424 \pm 1.913$ & $13.080 \pm 1.701$ & 0.950 & 0.344 \\
\hline After & $\begin{array}{l}\text { Mean } \\
\pm \text { SD }\end{array}$ & $12.140 \pm 1.520$ & $11.380 \pm 1.517$ & 2.503 & $0.014 *$ \\
\hline Differences & $\begin{array}{l}\text { Mean } \\
\pm \text { SD }\end{array}$ & $1.284 \pm 1.431$ & $1.700 \pm 1.677$ & & \\
\cline { 1 - 5 } Paired Test & $\begin{array}{l}\text { P- } \\
\text { value }\end{array}$ & $<0.001 *$ & $<0.001^{*}$ & & \\
\hline
\end{tabular}

Table (6): Compares the development of anemia with sofosbuvir, daclatasvir and ribavirin regimen in patients above and below 60 years: shows no significant difference

\begin{tabular}{|c|c|c|c|c|c|}
\hline \multirow{2}{*}{\multicolumn{2}{|c|}{$\begin{array}{c}\text { Hb Sofosubuvir } \\
\text { Daclatasvir and } \\
\text { Ribavirin }\end{array}$}} & \multicolumn{2}{|c|}{ Subgroups } & \multicolumn{2}{|c|}{ T-Test } \\
\hline & & Group A & Group B & $\mathbf{T}$ & P-value \\
\hline Before & $\begin{array}{l}\text { Mean } \\
\pm \text { SD }\end{array}$ & $\begin{array}{c}13.596 \pm \\
1.661\end{array}$ & $\begin{array}{c}13.252 \pm \\
2.156\end{array}$ & 0.632 & 0.530 \\
\hline After & $\begin{array}{l}\text { Mean } \\
\pm \text { SD }\end{array}$ & $\begin{array}{c}12.436 \pm \\
1.489\end{array}$ & $\begin{array}{c}11.844 \pm \\
1.522 \\
\end{array}$ & 1.390 & 0.171 \\
\hline Differences & $\begin{array}{l}\text { Mean } \\
\pm \text { SD }\end{array}$ & $\begin{array}{c}1.160 \pm \\
1.416\end{array}$ & $\begin{array}{c}1.408 \pm \\
1.464\end{array}$ & & \\
\hline Paired Test & $\begin{array}{l}\text { P- } \\
\text { value }\end{array}$ & $<0.001 *$ & $<0.001 *$ & & \\
\hline
\end{tabular}

Table (7): Compares the development of anemia with quervo and ribavirin regimen in patients above and below 60 years: shows no significant difference

\begin{tabular}{|c|c|c|c|c|c|}
\hline \multirow{2}{*}{\multicolumn{2}{|c|}{$\begin{array}{c}\text { Hb Quervo } \\
\text { and Ribavirin }\end{array}$}} & \multicolumn{2}{|c|}{ Subgroups } & \multicolumn{2}{|c|}{ T-Test } \\
\hline & & Group A & Group B & $\mathbf{T}$ & P-value \\
\hline Before & $\begin{array}{l}\text { Mean } \\
\pm \text { SD }\end{array}$ & $\begin{array}{c}13.396 \pm \\
1.632\end{array}$ & \begin{tabular}{|c|}
$12.764 \pm$ \\
1.742
\end{tabular} & 1.324 & 0.192 \\
\hline After & $\begin{array}{l}\text { Mean } \\
\pm \text { SD }\end{array}$ & $\begin{array}{c}11.644 \pm \\
1.427\end{array}$ & \begin{tabular}{|c|}
$11.116 \pm$ \\
1.587
\end{tabular} & 1.237 & 0.222 \\
\hline Differences & $\begin{array}{l}\text { Mean } \\
\pm \text { SD }\end{array}$ & $\begin{array}{c}1.752 \pm \\
1.702\end{array}$ & $\begin{array}{c}1.648 \pm \\
1.684\end{array}$ & & \\
\hline Paired Test & P-value & $<0.001^{*}$ & $<0.001^{*}$ & & \\
\hline
\end{tabular}

Table (8): Compares the development of hyperbilirubinemia with both regimens: shows significant increase of hyper-bilirubinemia with quervo and ribavirin regimen

\begin{tabular}{|c|c|c|c|c|c|}
\hline \multirow{2}{*}{\multicolumn{2}{|c|}{ TBI }} & \multicolumn{2}{|c|}{ Groups } & \multicolumn{2}{|c|}{ T-Test } \\
\hline & & \begin{tabular}{|c|}
$\begin{array}{c}\text { Sofosubuvir } \\
\text { Daclatasvir and } \\
\text { Ribavirin }\end{array}$ \\
\end{tabular} & $\begin{array}{l}\text { Quervo and } \\
\text { Ribavirin }\end{array}$ & $\mathbf{T}$ & P-value \\
\hline Before & $\begin{array}{l}\text { Mean } \\
\pm \text { SD }\end{array}$ & $1.009 \pm 0.510$ & $0.792 \pm 0.222$ & 2.768 & $0.007 *$ \\
\hline After & $\begin{array}{l}\text { Mean } \\
\pm \text { SD }\end{array}$ & $0.923 \pm 0.443$ & $0.930 \pm 0.486$ & $\mid \begin{array}{c}- \\
0.077\end{array}$ & 0.938 \\
\hline Differences & $\begin{array}{l}\text { Mean } \\
\pm \text { SD }\end{array}$ & $0.087 \pm 0.513$ & $-0.138 \pm 0.460$ & & \\
\hline $\begin{array}{l}\text { Paired } \\
\text { Test }\end{array}$ & \begin{tabular}{|l|} 
P- \\
value
\end{tabular} & 0.238 & $0.039 *$ & & \\
\hline
\end{tabular}

Table (9): Compares the effect of gender on development of complication with treatment with both regimens: shows that development of anemia more common with female in both regimens

\begin{tabular}{|c|c|c|c|c|c|}
\hline \multirow{3}{*}{ Groups } & & \multicolumn{2}{|c|}{ Gender } & \multirow{2}{*}{\multicolumn{2}{|c|}{ T-Test }} \\
\hline & & Male & Female & & \\
\hline & & Mean \pm SD & Mean \pm SD & $\mathbf{T}$ & P-value \\
\hline \multirow{4}{*}{$\begin{array}{l}\text { Sofosubuvir } \\
\text { Daclatasvir } \\
\text { and Ribavirir }\end{array}$} & HbBefore & $14.295 \pm 1.766$ & $12.739 \pm 1.764$ & 3.095 & $0.003^{*}$ \\
\hline & Hb After & $12.764 \pm 1.345$ & $11.650 \pm 1.489$ & 2.737 & $0.009 *$ \\
\hline & TBI Before & $0.973 \pm 0.402$ & $1.038 \pm 0.587$ & -0.441 & 10.661 \\
\hline & TBI After & $0.915 \pm 0.318$ & $0.929 \pm 0.527$ & -0.109 & \begin{tabular}{|l|l|}
9 & 0.914 \\
\end{tabular} \\
\hline \multirow{4}{*}{$\begin{array}{l}\text { Quervo } \\
\text { and Ribavirir }\end{array}$} & Hb Before & $13.767 \pm 1.557$ & $12.583 \pm 1.649$ & 2.564 & $0.014 *$ \\
\hline & Hb After & $11.871 \pm 1.556$ & $11.024 \pm 1.409$ & 2.009 & $0.050 *$ \\
\hline & nTBI Before & $0.848 \pm 0.236$ & $0.751 \pm 0.206$ & 1.539 & 0.130 \\
\hline & TBI After & $1.057 \pm 0.582$ & $0.838 \pm 0.387$ & 1.601 & 0.116 \\
\hline
\end{tabular}

\section{DISCUSSION}

This study was applied on 100 patients divided into two groups each group received one of both treatment regimen then each group subdivided into two sub groups, subgroup A containing 25 patients below 60 years and subgroup B containing 25 patients above 60 years. The study include 43 males and 57 females, 21 of males and 29 of 
females received quervo and ribavirin regimen, while 22of males and 28 of females received sosfsbuvir, daclatasvir and ribavirin regimen. This study shows that both regimens achieved high efficacy with $p$ value of both $<0.05$ and no significant differences between them $\mathrm{p}$ value 0.377 . Gender and age don't affect outcome of treatment with $p$ value ( 0.977 with sosfsbuvir, daclatasvir and ribavirin regimen, 0.262 with quervo and ribavirin regimen as regarding gender) and (0.244 with sosfsbuvir, daclatasvir and ribavirin regimen, 0.348 with quervo and ribavirin regimen as regarding age) and this is in agreement with Abdel-Moneim et al. ${ }^{(6)}$, and Ahmed et al. ${ }^{(7)}$, that reported Sofosbuvir plus daclatasvir, with or without ribavirin achieved high efficacy and safety in HCV genotype 4 patients. Their effect were accompanied with attenuation of liver fibrosis. Patients treated with sosfsbuvir, daclatasvir and ribavirin regimen shows efficacy 94 $\%$ and this matched with Omar et al. ${ }^{(8)}$ study, that including >18,000 Egyptian patients with HCV infection, about 95\% achieved SVR 12. It was concluded that sofosbuvir plus daclatasvir with or without ribavirin regimen is safe and effective for the treatment of Egyptian patients with chronic hepatitis C genotype 4. Also in agreement with $\mathbf{P o l}$ et al. ${ }^{(9)}$ study that documented the combination of sofosbuvir and daclatasvir with or without ribavirin had high antiviral potency, with $>90 \%$ SVR rate in patients with chronic HCV infection. This study agrees with Fontaine et al. ${ }^{(10)}$ study that concluded the combination of sofosbuvir and daclatasvir was associated with a high rate of SVR in treatment of genotype 4 HCV. SVR was $86 \%-100 \%$, according to patients' baseline characteristics and therapeutic regimen. Patients treated with Quervo and ribavirin regimen shows efficacy $96 \%$ and this matched with Crespo et al. ${ }^{(11)}$ study that reported high SVR rates of $96.2 \%$ were reported in HCV GT4 infected patients treated with OBV/PTV/r $(n=122)$ with or without RBV. This study shows little differences with David and Nina ${ }^{(12)}$ study that examined the efficacy of a 12-week course of ombitasvir plus paritaprevir plus ritonavir with or without ribavirin in adults with chronic $\mathrm{HCV}$ genotype 4 infection; For the 86 treatmentnaïve recipients of ombitasvir plus paritaprevir plus ritonavir without ribavirin, an SVR12 was achieved in $91 \%$ (40 of 44) compared with an SVR12 rate of $100 \%$ (42 of of 42) in participants treated with ombitasvir plus paritaprevir plus ritonavir with ribavirin. The study, showed an excellent treatment response with a 24-week regimen of ombitasvir plus paritaprevir plus ritonavir for genotype 4 infection, particularly if ribavirin is added to the regimen. Gretja et al. ${ }^{(13)}$ study reported that SVR12 rate of $100 \%$ were observed among GT4- infected treatment naïve and treatment experienced patients receiving ombitasvir plus paritaprevir with RBV. In the current study with sosfsbuvir, daclatasvir and ribavirin regimen (24/25) of patients above 60 years achieved SVR12, while (23/25) of patients below 60 years achieved SVR 12 and with quervo and ribavirin regimen (24/25) of patients above 60 years achieved SVR12 and the same with patients below 60 years. So age doesn't affect treatment outcome and this is in agreement with Conti et al. ${ }^{(14)}$ study that demonstrated age per se dose not influence the success of IFN- free treatments in elderly patients with $\mathrm{CHC}$ and that all DAA regimens seem well tolerated and safe, also in subjects with advanced liver disease and in those aged 75 years or older. Also Ossama et al. ${ }^{(15)}$ study shows that neither age nor any of the pretreatment biochemical markers including hemoglobin, leukocytic count, platelet count, ALT, AST, albumin, INR, bilirubin, and PCR for HCV RNA showed significant correlation with treatment outcome. (27/28) of females treated with sosfsbuvir, daclatasvir and ribavirin regimen achieved SVR12, the female that doesn't achieve SVR, is below 60 years. (28/29) of female treated with quervo and ribavirin regimen achieved SVR12, the female that doesn't respond is above 60 years. So gender does not affect treatment outcome and this is similar to Paola et al. ${ }^{(16)}$ study that did not identify meaningful association between virological responses and gender. In this study (17/50) $34 \%$ of patients receiving sosfsbuvir, daclatasvir and ribavirin regimen developed anemia with $\mathrm{p}$ value $<0.001,(10 / 25)$ of them above age of 60 and (11/28) of them were females. There is increased incidence of anemia with females $p$ value before treatment was 0.003 and after treatment was 0.009 . Age doesn't increase incidence of anemia $p$ value 0.171 . While occurance of hyperbilirubinemia (6/50) $12 \%$ of patients is not significant in this regimen $\mathrm{p}$ value 0.238. 29/50) $58 \%$ of patients receiving quervo and ribavirin regimen developed anemia with $\mathrm{p}$ value $<0.001,(15 / 25)$ of them above age of 60 and (16/29) of them were females. There is increased incidence of anemia with females $p$ value before treatment was 0.014 and after treatment was 0.050 . Age doesn't 
increase incidence of anemia $\mathrm{p}$ value 0.222 . Occurrence of hyperbilirubinemia (9/50) $18 \%$ of patients is significant in this regimen with $\mathrm{p}$ value 0.039. In comparison between two regimens there is increased incidence of anemia more with quervo and ribavirin regimen with $\mathrm{p}$ value 0.014 . In case of comparison of hyperbilirubinemia between two regimens although $\mathrm{p}$ value is 0.938 (nonsignificant) although there is significant increase with quervo and ribavirin regimen it is due to increases bilirubin before treatment with sosfsbuvir, daclatasvir and ribavirin regimen with $\mathrm{p}$ value before treatment was 0.007 . Female gender shows increased incidence of anemia before and after treatment with both regimens. As regarding anemia, this study is mismatched with Poordad et al. ${ }^{(17)}$ study that reported daclatasvir in combination with sofosbuvir and ribavirin developed anemia in (20\%) of patients. In Ahmed et al. ${ }^{(7)}$ study, non-cirrhotic naïve patients were treated with sofosbuvir plus daclatasvir for 12 weeks. Ribavirin was added to this regimen when treating cirrhotic patients and/ or treatment experienced patients. The adverse event was anemia in $(5.67 \%)$ of patients. Blaise et al. ${ }^{(18)}$ reported about Safety profile of different SOF combination that the mean change in haemoglobin level associated with regimens that contained RBV versus those that didn't contain RBV was $-2.4 \mathrm{~g} / \mathrm{dl}$ versus $-0.4 \mathrm{~g} / \mathrm{dl}$ after 12 weeks of therapy, and this is in agreement with this study that shows the mean change in haemoglobin level (1.284 \pm 1.431$)$. Attia et al $^{\left({ }^{(19)}\right.} \mathrm{In}$ this retrospective multicenter study adverse events were reported in 5 patients out of 101 who received $\mathrm{PTV} / \mathrm{OBV} / \mathrm{r} / \mathrm{RBV}$ regimen, mean age was $(61+/-5$ years old) one had anaemia, one had hyperbilirubinemia and 3 patients had non-specific side effects. SOF / DCV / RBV also showed hepatobiliary complication in $31 \%$ of the developed side effects, and were $(92 / 45188,0.2 \%)$ in the treated patients' group. Haematological complications were $(96 / 45188,0.2 \%)$ in treated patients with anaemia being the most common one $(76 / 45188,0.16 \%)$ in treated patients. This study is in agreement with Hironao et al. ${ }^{(20)}$ and Menon et al. ${ }^{(2 I)}$ studies that reported during treatment with ombitasvir, paritaprevir, and ritonavir with or without ribavirin, mild to moderate increase in serum bilirubin concentration, has been reported in some cases. Liu et al. ${ }^{(22)}$ documented that in patients receiving paritaprevir, $23 \%$ had elevation in total bilirubin $(>2.25 \mathrm{mg} / \mathrm{dl})$, mainly indirect (unconjugated) bilirubin levels, without elevation in liver enzymes.

\section{CONCLUSION}

This study shows that treatment with (sofosbuvir daclatasvir and ribavirin regimen) or (quervo and ribavirin regimen) is highly effective with little differences between them, also age and gender have no role in achieving SVR. Patients in this study developed some complications as anemia and hyperbilirubinemia that occur in treatment with both regimens and more frequent with (quervo and ribavirin regimen).

\section{CONFLICTS OF INTEREST}

There are no conflicts of interest.

\section{REFERENCES}

\section{1- Thein HH, Yi Q, Dore GJ, Krahn MD} (2008): Estimation of stage-specific fibrosis progression rates in chronic hepatitis $\mathrm{C}$ virus infection: a metaanalysis and meta-regression. Hepatology, 48(2):418-31.

2- EL-Serag HB, Rudolph $K$ (2007): Hepatocellular carcinoma: epidemiology and molecular carcinogenesis. Gastroenterology, 132(7):2557-76

3- Marcus EL, Tur-Kaspa R (2005): Chronic hepatitis $\mathrm{C}$ virus infection in older adults. Clin Infect Dis., 41(11):1606-12

4- Hezode C, Asselah T, Reddy KR, Hassanein $\mathrm{T}$, Berenguer $\mathrm{M}$ et al. (2015): Ombitasvir plus paritaprevir plus ritonavir with or without ribavirin in treatment naïve and treatment experienced patients with genotype 4 chronic hepatitis $\mathrm{C}$ virus infection (PEARL-1): a randomized, open label trial. Lancet, 385(9986):2502-9.

5- Herbst DA, Reddy KR (2013): Sofosbuvir, a nucleotide polymerase inhibitor, for the treatment of chronic hepatitis $\mathrm{C}$ virus infection. Expert Opin Investing Drugs, 22(4):527-36.

6- Abdel-Moneim A, Aboud A, AbdelGabaar M, Zanaty MI, Ramadan M (2018): Efficacy and safety of sofosbuvir plus daclatasvir with or without ribavirin: large real life results of patients with chronic hepatitis $\mathrm{C}$ genotype 4. Hepatol Int., doi: 10.1007/s12072-018-9868-8 
7- Ahmed OA, Elsebaey MA, Fouad MHA, Elashry H, Elshafie Al et al. (2018): Outcomes and predictors of treatment response with sofosbuvir plus daclatasvir with or without ribavirin in Egyptian patients with genotype 4 hepatitis $C$ virus infection. Infect Drug Resist., 11: 441-445

8- Omar H, EL-Akel W, Elbaz T, El Kassas M, Elsaeed K et al. (2018): Generic daclatasvir plus sofosbuvir, with or without ribavirin, in treatment of chronic hepatitis C: real world results from 18378 patients in Egypt. Aliment Pharmacol ther., 47(3):421-431.

9- Pol S, Corouge M, Vallet-Pichard A (2016): Daclatasvir- sofosbuvir combination therapy with or without ribavirin hepatitis $\mathrm{C}$ virus infection: from the clinical trial to real life. Hepat Med., 4;8:21-6.

10- Fontaine H, Hezode C, Zoulim F, Didier SAMUEL, Marc B et al. (2015): Efficacy of the oral sofosbuvir based combinations in HCV genotype 4monoinfected patients from the French observational cohort ANRS CO22 Hepather., Vienne, Austria. https://www.researchgate.net/scientificcontributions/2081435979_H_Fontaine

11- Crespo J, Calleja JL, Fernández I, Sacristan B, Ruiz-Antorán B et al. (2017): Real world effectiveness and safety of oral combination antiviral therapy for hepatitis $\mathrm{C}$ virus genotype 4infection. Clin Gastroenterol Hepatol., 15(6):945-949.e1.

12- David HS, Nina HK (2017): Treatment of HCV Genotype 4 November 15th , Hepatitis C .https://www.hepatitisc.uw.edu/ go/treatment-infection/treatment-genotype4/core-concept/all

13- Gretja S, Rakesh T, Jill B, Thomas R, Preethi K et al. (2015): Hepatitis C Virus Genotype 4 Resistance and Subtype Demographic Characterization of Patients Treated with Ombitasvir plus Paritaprevir/ Ritonavir. Antimicrob Agents Chemother., 59(11):6807-15.

14- Conti F, Brillianti S, Buonfiglioli F, Vukoti R, Morelli MC et al. (2016): Safety and efficacy of direct acting antivirals for the treatment of chronic hepatitis $\mathrm{C}$ in a real world population aged 65 years and older. Journal of viral hepatitis, 24(6):454-463.
15- Ossama AA, Eslam S, Mohamed OK, Ahmed IE, Mohamed $\mathrm{H}$ et al. (2018): Sofosbuvir plus daclatasvir in Treatment of Chronic Hepatitis C Genotype 4 Infection in a Cohort of Egyptian Patients: An Experiment the Size of Egyptian Village. Int J Hepatol., 2018: 9616234

16- Paola B, Alessandro C, Maria M, Andrea E, Sara G et al. (2016): Can gender predict virological response to standard antiviral therapy for chronic hepatitis C? A retrospective study. Hepatoma research, doi:10.20517/2394-5079.2015.53

17- Poordad F, Schiff ER, Vierling JM, Landis C, Fontana RJ et al. (2016): Daclatasvir with sofosbuvir and ribavirin for hepatitis $\mathrm{C}$ virus infection with advanced cirrhosis or post liver transplantation recurrence. Hepatology, 63(5): 1493-505.

18- Blaise KK, Feryel M, Corinne C, Valerie B, Nathalie G et al. (2017): Efficacy and safety of sofosbuvir based therapies in patients with advanced liver disease in a real life cohort. Hepatic Medicine, 9: 67-73.

19- Attia D, El Saeed K, Elakel W, El Baz T, Omar A et al. (2018): The adeverse effects of interfere one-free regimens in 149816 chronic hepatitis C treated Egyptian patients. Alimentary pharmacology and therapeutic, 47(9):1296-1305.

20- Hironao O, Hitoshi A, Yushi S, Eisuke N, Hiroo F et al. (2018): Gadoxetic acidenhanced magnetic resonance imaging to predict paritaprevir- induced hyperbilirubinemia during treatment of hepatitis C. Plos one, https://doi.org/ 10.1371/journal.pone.0196747

21- Menon RM, Klein CE, Podsadeccki TJ, Chiu YL, Dutta S et al. (2016): Pharmacokinetics and tolerability of paritaprevir, a direct acting antiviral agent for hepatitis $\mathrm{C}$ virus treatment, with or without ritonavir in healthy volunteers. BR j Clin Pharmacol., 81(5): 929-940.

22- Liu CH, Liu CJ, Su TH, Yang HC, Hong CM et al. (2017): Real world effectiveness and safety of paritaprevir / ritonavir, ombitasvir, and dasabuvir with or without ribavirin for patients with chronic hepatitis $\mathrm{C}$ virus genotype $1 \mathrm{~b}$ infection in Taiwan. $\mathbf{J}$ Gastroenterol Hepatol., 33(3):710-717. 